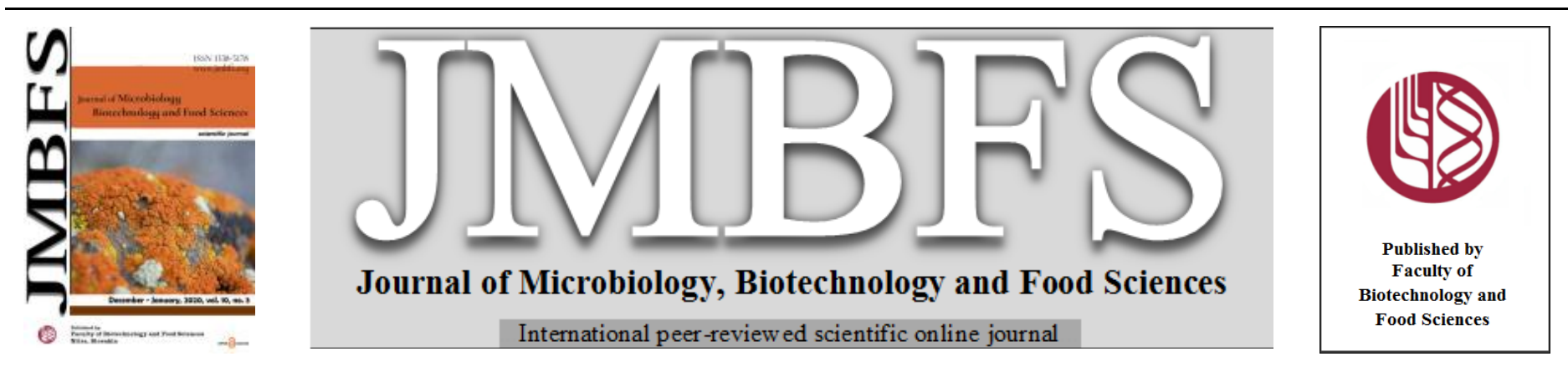

\title{
EFFECT OF TEMPERATURE, pH AND ESSENTIAL OILS ON THE MYCELIAL GROWTH OF RHIZOCTONIA SOLANI Kühn (CANTHARELLALES: CERATOBASIDIACEAE) ISOLATES
}

\author{
Imad Kotba ${ }^{1,2^{*}}$, Abdelaaziz Bouaichi ${ }^{1,2}$, Hanane Lougraimzi ${ }^{3}$, Khaoula Habbadi ${ }^{1,2}$, Azeddine Errifi ${ }^{1}$, Amina Ouazzani Touhami ${ }^{1}$, Allal \\ Douiral and El Hassan Achbani ${ }^{2}$
}

$\operatorname{Address}(e s)$ :

${ }^{1}$ Laboratory of Botany, Biotechnology and Plant Protection, Faculty of Sciences, Ibn Tofail University, P.O. Box 133, 14000 Kenitra, Morocco.

${ }^{2}$ Laboratory of Phytobacteriology and Biological Control, CRRA of INRA- Meknès, Km 11 Road hadj Kaddour / P.O. Box 578 VN 50000, Meknès, Morocco.

${ }^{3}$ Laboratory of Health, Nutrition and Environment, Faculty of Sciences, Ibn Tofail University, P.O. Box 133, 14000 Kenitra, Morocco.

*Corresponding author: kotba.imad@gmail.com

doi: 10.15414/jmbfs.2020.10.3.461-466

\section{ARTICLE INFO}

Received 3. 7. 2019

Revised 17. 9. 2020

Accepted 23. 9. 2020

Published 1. 12. 2020

Regular article OPEN $\partial_{\text {ACCESS }}$

\begin{abstract}
This research aimed to study diversity among a collection of Rhizoctonia solani strains, isolated from many crops in Morocco, based on radial mycelial growth on potato dextrose agar (PDA) at different $\mathrm{pH}$ and temperature levels. The in vitro antifungal efficacy of essential oils (EOs) derived from aromatic and medicinal plants of Thymus vulgaris, Origanum compactum, Rosmarinus officinalis, Eucalyptus sp., Salvia sp., Cistus ladanifer and Lavandula stoechas was also evaluated by measuring the mycelial growth of this plant pathogenic fungus after placing active mycelial plugs of each strain on Petri dishes using a disc diffusion method of EOs. The Minimum Inhibitory Concentration (MIC) of each EO was also determined. The growth rates observed under different temperatures and $\mathrm{pH}$ levels varied among isolates and did not show similar responses for the same levels of the two growth parameters. However, the maximum mycelial growth of the majority of isolates was reached between 20 and $30^{\circ} \mathrm{C}$ as well as at $\mathrm{pH}$ 7. Among the EOs tested, the results revealed that EO of Thymus vulgaris and Origanum compactum were very effective on controlling $R$. solani strain RS1 with growth inhibition rate of $75,9 \%$ and $60,6 \%$, respectively. The MIC of these EOs was at $0.03 \%$. According to the gas chromatography analysis, Carvacrol $(61.8 \%)$ and thymol (47.8\%) are the major constituents of O. compactum and T. vulgaris EOs, respectively, suggesting that these natural compounds have important potential to control $R$. solani and could be useful for developing effective organic fungicides.
\end{abstract}

Keywords: Rhizoctonia solani, Antifungal activity, Essential oil, Temperature, pH

\section{INTRODUCTION}

Rhizoctonia solani Kuhn (Teleomorph: Thanatephorus cucumeris) is one of the most serious soil-borne fungal pathogens, causing disease on a large number of host plant species (Sneh et al., 1991). Critical disease symptoms caused by this pathogen, on host plants, include Root, stem and crown rot and damping-off (Lahlali and Hijri, 2010; Naher et al., 2014). Many crops of economic importance worldwide are frequently affected by $R$. solani including potato, bean, tomato, soybean, strawberry and tulip, (Kotba et al., 2018; Lahlali and Hijri, 2010; Ismail \& Ismail, 2011; Naher et al., 2014). Isolates of this pathogen has a complex biology and diversity in terms of myclial colour, size of aerial mycelium, growth rate, zonation, type and number of sclerotia, saprophytic behaviour, enzyme production and pathogenicity (Hyakumachi et al., 1988; Salunkhe et al. 2008). In addition to the recognized methods to group isolates of $R$. solani taxonomically, diversity of growth character within different $\mathrm{pH}$ and temperatures levels has been noted by Chang (1985). The most favorable temperature level for $R$. solani development is $23-28^{\circ} \mathrm{C}$, while lower and higher optima have been noted for different isolates (Abe, 1978). Another report showed the optimal temperature between 25 to $35^{\circ} \mathrm{C}$ with the most convenient media were potato-dextrose-agar, malt-extract and Sabouraud-glucose (Csöndes $\boldsymbol{e t}$ al. 2007). In Morocco, no detailed information is available on the variability in $R$. solani species, in particular the diversity of isolates and their behavior under different $\mathrm{pH}$ and temperature regimes.

Chemical fungicides are often used to avoid the substantial yield losses caused by $R$. solani. However, the intensive use of chemical fungicides has not only created problems of fungicide resistance, but has also resulted in the increase of the soil contamination, high toxicity of microbial communities and a deterioration effect on the ozone layer (Huang et al., 2011). In addition, chemical control is not completely effective, and Rhizoctonia disease still damages diverse crops (Goudjal et al., 2014). To overcome this challenge, the use of plants extracts may be an alternative to conventional fungicides to control $R$. solani. The activity pathway of these biopesticides against fungi is unrevealed but may be interrelated to their general capability to soften or otherwise dislocate the reliability of cell membranes and cell walls (Isman, and Machial, 2006). The objectives of this study were to i) demonstrate the existing diversity among $R$. solani isolates based on growth at different $\mathrm{pH}$ and temperature regimes on culture media, ii) determine the efficacy of some plant-derived EOs against the growth of $R$. solani in laboratory assays, iii) identify the major constituents of these oils by gas chromatography method using appropriate detectors.

\section{MATERIAL AND METHODS}

\section{Rhizoctonia solani isolates}

Naturally diseased plants of different crops (melon, water melon, sugar beet, bean, olive tree, strawberries, potato and tomato) showing typical symptoms of root rot disease were collected from several locations in Morocco (Tab1). For fungal isolation, the collected plant roots were washed carefully under running tap water followed by sterile water, then dried between two filter papers. Roots were cut into small pieces, that were transferred into ethanol $70^{\circ}$ during 3 min for surface sterilization. Surface sterilized pieces were then washed several times with sterilized water to wash out the remaining disinfectant solution. The pieces were then dried on sterilized filter papers. Using sterilized forceps, plot dried pieces were then transferred into Petri dishes containing potato dextrose agar medium (PDA) (Rashad et al., 2012). Concerning potato tubers, sclerotia (black scurf) detached from tubers were disinfected in ethanol $70^{\circ}$ for $1 \mathrm{~min}$, then washed with sterile distilled water and dried on sterile filter paper. Disinfected sclerotia were divided in many pieces and left to culture on PDA medium (Djébali et al., 2014). The dishes were then incubated at $25 \pm 1^{\circ} \mathrm{C}$, and the fungal growth were checked two days after incubation. In order to obtain pure cultures, purification of the isolates was done using the hyphal tip technique (Rashad $\boldsymbol{e t}$ al., 2012). Identification of the pure isolates were done according to the cultural properties, in particular morphological and microscopical characteristics (Sneh et al., 1991). 
Table 1 Host origin and plant part studied of $R$. solani isolates

\begin{tabular}{lccc}
\hline Strain code & Host plant & $\begin{array}{c}\text { Host location } \\
\text { (City) }\end{array}$ & $\begin{array}{c}\text { Plant part } \\
\text { studied }\end{array}$ \\
\hline RS1 & Tomato & Menasra (Kenitra) & Collar \\
\hline RS3 & Melon & Menasra (Kenitra) & Root system \\
\hline RS4 & Sugar beet & Berkane & Tuber \\
\hline RS5 & Bean & Agadir & Root system \\
\hline RS6 & Olive tree & Marrakech & Root system \\
\hline RS7 & Strawberries & Kenitra & Root system \\
\hline RS8 & Potato & Berkane & Tuber \\
\hline RS9 & Potato & Agadir & Tuber \\
\hline RS10 & Potato & Agadir & Tuber \\
\hline RS11 & Potato & Fes & Tuber \\
\hline RS12 & Potato & Agadir & Tuber \\
\hline RS13 & Potato & Agadir & Tuber \\
\hline RS14 & Potato & Agadir & Tuber \\
\hline RS15 & Potato & Rabat & Tuber \\
\hline RS16 & Potato & Casablanca & Tuber \\
\hline RS17 & Water melon & $\begin{array}{c}\text { Laouamra } \\
\text { (Larache) }\end{array}$ & Root system \\
\hline
\end{tabular}

Effect of temperature on mycelial growth of $R$. solani isolates

Different temperature levels $5 ; 10 ; 15 ; 20 ; 25 ; 30 ; 33$ and $35^{\circ} \mathrm{C}$ were evaluated in this trial. Fifteen milliliters of PDA media were added into each of the Petri dish ( $9 \mathrm{~cm}$ diameter) then an agar plug of fungal inoculums $(4 \mathrm{~mm}$ diameter) was cut aseptically with a sterile scalpel from the margin of 2 days old culture of the sixteen $R$. solani isolates. One disc was placed in the center of individual Petri dish and three dishes were used for each isolate. After inoculation, the Petri dishes were incubated maintaining every time one of the eight temperature levels. Radial mycelial growth was calculated by averaging the two diameters taken at right angle of each colony when mycelial growth of some isolates reached the edge of the Petri dish (Goswami et al., 2011).

\section{Effect of pH on mycelial growth of $R$. solani isolates}

Five different levels of $\mathrm{pH}$ " $5 ; 6 ; 7 ; 8$ and 8.5 " were maintained to study the isolates mycelial growth variation at different $\mathrm{pH}$ levels adjusted by adding $\mathrm{HCl}$ or $\mathrm{NaOH}$ before solidifying the PDA media (Goswami et al., 2011). The method followed for inoculation of mycelial discs of $R$. solani isolates with five $\mathrm{pH}$ levels was the same as described before. After inoculation, the Petri plates were incubated at $25 \pm 1^{\circ} \mathrm{C}$. Radial mycelial growth was calculated by averaging the two diameters taken at right angles for each colony when mycelial growth of some isolates reached the edge of the Petri dish.

In order to facilitate the conduct of the other tests, eight representatives isolates were selected from the sixteen isolates. This selection was based on the origin (plant) of isolates and the average growth rates $(\mathrm{mm} / \mathrm{d})$ of the sixteen isolates under different temperature and $\mathrm{pH}$ levels. The eight isolates selected were RS1, RS3, RS4, RS5, RS6, RS7, RS8 and RS17.

\section{Extraction of essential oils from aromatic and medicinal plants}

Aromatic and medicinal plants used in this research are listed in Tab 2. The plant material was collected from three different locations in Morocco then was dried under the shade condition. The EO was extracted by hydrodistillation of the dried plants, using a Clevenger-type apparatus. The EOs were then collected by decantation, dried using anhydrous sodium sulfate, weighted, and stored in a dark glass bottle at $4^{\circ} \mathrm{C}$ (Negahban et al., 2007).

Table2 Medicinal and aromatic plants studied

\begin{tabular}{lcll}
\hline Common name & Scientific name & $\begin{array}{c}\text { Botanical } \\
\text { family }\end{array}$ & $\begin{array}{c}\text { Plant part } \\
\text { used }\end{array}$ \\
\hline Cistus & Cistus ladanifer $\mathrm{L}$. & Cistaceae & Leaves \\
\hline Lavander & $\begin{array}{c}\text { Lavandula stoechas } \mathrm{L} . \\
\text { Oregano }\end{array}$ & $\begin{array}{c}\text { Lamiaceae } \\
\text { Origanum compactum } \\
\text { Benth. }\end{array}$ & Flowers \\
\hline Rosemary & $\begin{array}{c}\text { Rosmarinus officinalis } \\
\text { L. }\end{array}$ & Lamiaceae & Leaves \\
\hline Thyme & Thymus vulgaris $\mathrm{L}$. & Lamiaceae & Leaves \\
\hline Eucalyptus & Eucalyptus $s p$. & Myrtaceae & Leaves \\
\hline Sage & Salvia $s p$. & Lamiaceae & Leaves \\
\hline
\end{tabular}

Antifungal activity evaluation

Petri dishes with $9 \mathrm{~cm}$ diameter and containing $20 \mathrm{ml}$ of PDA media were used to evaluate the antifungal activity of EOs by the disc diffusion method (Duru et al. 2003). Sterile Whatman paper discs of $6 \mathrm{~mm}$ diameter were placed on the PDA media, equidistant and near the border, where the EO $(5 \mu \mathrm{L} /$ disc $)$ was added separately. An agar plug of fungal inoculums $(6 \mathrm{~mm}$ diameter) was removed from a young culture of the eight fungal strains studied, and placed near the other border of the Petri dishes. The plates were incubated at $25 \pm 1^{\circ} \mathrm{C}$ for 5 days, until the growth in the control plates reached the edge of the plates. Concerning the control, $5 \mu \mathrm{L}$ of sterilized water was added to each disc. For each treatment, plates were prepared in triplicate and the percentage of growth inhibition was calculated using the following formula (Topps and Wain 1957):

Inhibition $(\%)=[\mathrm{A}-\mathrm{B} / \mathrm{A}] \times 100$

A: Radial growth of control (mm)

B: Radial growth of treatment (mm)

\section{Determination of Minimum Inhibitory Concentrations (MICs)}

The MIC values of $R$. solani isolates were detremined following the agar dilution method as defined previously by Gul $\boldsymbol{e t}$ al. (2002). Appropriate volume of the EO was added aseptically to sterile molten PDA medium to produce the concentration range of $0,01 \%$ - $0,5 \%$. After vortexing, the resulting PDA solutions were immediately poured into Petri plates. An agar plug of fungal inoculums (6 $\mathrm{mm}$ diameter) was removed from a young culture of all the fungal isolate tested, and placed in the center of the Petri dishes. The plates were prepared in triplicate for each treatment and were incubated at $25 \pm 1{ }^{\circ} \mathrm{C}$ for 5 days, until the growth in the control plates (PDA not mixed with EOs) reached the edge of the plates. The MIC values were determined as the lowest concentrations of the EO where the absence of growth was recorded.

\section{Characterization of essential oils by Gas Chromatography analysis}

Determination of the EOs chemical composition was done using a HewlettPackard model HP6890 gas chromatograph (Agilent Technologies, Palo Alto, CA, USA) equipped with a DB-5MS capillary column $(30 \mathrm{~m} \times 0.25 \mathrm{~mm}$ i.d., film thickness $0.25 \mu \mathrm{m}$; Agilent Technologies, USA) and coupled to an HP model 5973 mass selective detector. The column temperature is programmed from 50 to $300{ }^{\circ} \mathrm{C}$ with an increase of $7{ }^{\circ} \mathrm{C} / \mathrm{min}$. The injector temperature was $290{ }^{\circ} \mathrm{C}$. Purified helium was used as a carrier gas with a flow rate of $1 \mathrm{~mL} / \mathrm{min}$, and the split ratio was 60:1. Mass spectra (MS) was obtained, in EI mode, at 70-eV ionization energy and the mass range was from 35 to $400 \mathrm{~m} / \mathrm{z}$. $10 \mu \mathrm{L}$ of each EO was diluted in $990 \mu \mathrm{L}$ of pure hexane, and for the analysis $1 \mu \mathrm{L}$ was injected. The apparatus was piloted by an HP electronic system equipped with a ChemStation Software "G1701BA, version B.01.00", and the data were analysed out with the same software. After each compound analysis, the Kovats retention index (RI) was calculated comparing to a standard mix of $\mathrm{n}$-alkanes between $\mathrm{C} 8$ and $\mathrm{C} 26$ (Sigma-Aldrich Co.) analyzed under same conditions. The components were identified by comparing the IR and MS spectra with those reported in the literature (Adams 2007, Habbadi et al., 2018) and by computer matching using standard reference databases (NIST98, Wiley275, and CNRS libraries).

\section{Statistical analysis}

Analysis of variance (ANOVA) was used to analyse results related to the effects of plant EOs on mycelial growth of $R$. solani strains and to check the existence of variability among $R$. Solani strains under different temperature and $\mathrm{pH}$ regimes on PDA media. Least Significant Difference (LSD) test was used at the 5\% level of significance; Statistical analysis was performed using SAS statistic software.

\section{RESULTS}

\section{Effect of temperature on mycelial growth of $R$. solani isolates}

According to the ANOVA results, there is significant interaction between $R$. solani isolates and temperature $(\mathrm{P}<0.0001)$ and significant main effect of both temperature and isolates on growth rate (Tab 3). Comparison between the sixteen isolates showed that isolates don't develop under $5^{\circ} \mathrm{C}$ and $35^{\circ} \mathrm{C}$ except isolate $\mathrm{RS} 7$ under $35^{\circ} \mathrm{C}$ with the average growth rate $(9.6 \mathrm{~mm} / \mathrm{d})$ (Table 4). Under temperatures $10^{\circ} \mathrm{C}, 15^{\circ} \mathrm{C}, 20^{\circ} \mathrm{C}, 25^{\circ} \mathrm{C}, 30^{\circ} \mathrm{C}$ and $33^{\circ} \mathrm{C}$, there is a significant difference among isolates. Also, under $30^{\circ} \mathrm{C}$, isolates RS1, RS3 and RS17 showed high average growth rate $(13.2 \mathrm{~mm} / \mathrm{d}$ for each isolate). Average growth rate revealed significant difference among different temperature levels for each isolate. For the majority of our isolates, there is no significant difference on the average growth rate between $20^{\circ} \mathrm{C}$ and $30^{\circ} \mathrm{C}$. In addition, the growth rate started to decline and revealed very low values for temperatures above $30^{\circ} \mathrm{C}(\mathrm{Tab}$ 4). 
Table 3 Analysis of variance (ANOVA) on growth rate of $R$. solani isolates under temperature level effect

\begin{tabular}{lccc}
\hline Source of variation & Degree of freedom & F-value & P-value \\
\hline Isolate $(\mathbf{I})$ & 15 & 48.00 & $<.0001$ \\
\hline Temperature $(\mathbf{T})$ & 7 & 758.14 & $<.0001$ \\
\hline $\mathbf{I} \times \mathbf{T}$ & 105 & 22.27 & $<.0001$ \\
\hline Block & 2 & 1.24 & 0.2913 \\
\hline
\end{tabular}

Within column, means followed by same lower case letters are not significantly different based on the LSD.

Within row, means followed by same upper case letters are not significantly different based on the LSD.

Table 4 Average growth rates $(\mathrm{mm} / \mathrm{d})$ of $R$. solani isolates under eight temperature levels

\begin{tabular}{lcccccccc}
\hline Isolate & $\mathbf{5}^{\circ} \mathbf{C}$ & $\mathbf{1 0}^{\circ} \mathbf{C}$ & $\mathbf{1 5}^{\circ} \mathbf{C}$ & $\mathbf{2 0}^{\circ} \mathbf{C}$ & $\mathbf{2 5}^{\circ} \mathbf{C}$ & $\mathbf{3 0}{ }^{\circ} \mathbf{C}$ & $\mathbf{3 3}^{\circ} \mathbf{C}$ & $\mathbf{3 5}^{\circ} \mathbf{C}$ \\
\hline RS1 & $0.0 \mathrm{Da}$ & $7.2 \mathrm{Cbc}$ & $2.0 \mathrm{Dh}$ & $9.3 \mathrm{BCa}$ & $\begin{array}{c}12.7 \\
\text { Aba }\end{array}$ & $13.2 \mathrm{Aa}$ & $10.1 \mathrm{ABCc}$ & $0.0 \mathrm{Db}$ \\
\hline RS3 & $0.0 \mathrm{Ea}$ & $7.2 \mathrm{CDbc}$ & $6.5 \mathrm{Ded}$ & $9.3 \mathrm{BCa}$ & $12.0 \mathrm{Aa}$ & $13.2 \mathrm{Aa}$ & $11.4 \mathrm{Aba}$ & $0.0 \mathrm{~Eb}$ \\
\hline RS4 & $0.0 \mathrm{Da}$ & $7.2 \mathrm{Abc}$ & $0.0 \mathrm{Di}$ & $2.3 \mathrm{Cb}$ & $5.4 \mathrm{Bf}$ & $4.8 \mathrm{Bf}$ & $4.1 \mathrm{Bd}$ & $0.0 \mathrm{Db}$ \\
\hline RS6 & $0.0 \mathrm{Da}$ & $4.8 \mathrm{Ced}$ & $6.0 \mathrm{Cef}$ & $9.8 \mathrm{Ba}$ & $12.0 \mathrm{Aa}$ & $12.0 \mathrm{Aa}$ & $10.4 \mathrm{Bbc}$ & $0.0 \mathrm{Db}$ \\
\hline RS7 & $0.0 \mathrm{Ea}$ & $0.0 \mathrm{Ef}$ & $11.0 \mathrm{BCa}$ & $\begin{array}{c}10.5 \\
\text { BCa }\end{array}$ & $12.7 \mathrm{Aa}$ & $10.5 \mathrm{Cb}$ & $11.2 \mathrm{Bab}$ & $9.6 \mathrm{Da}$ \\
\hline RS8 & $0.0 \mathrm{Ea}$ & $6.0 \mathrm{Ccd}$ & $7.4 \mathrm{Bd}$ & $9.2 \mathrm{Aa}$ & $9.7 \mathrm{Ac}$ & $9.4 \mathrm{Abc}$ & $1.8 \mathrm{De}$ & $0.0 \mathrm{~Eb}$ \\
\hline RS9 & $0.0 \mathrm{Ca}$ & $7.0 \mathrm{Bbc}$ & $8.9 \mathrm{Ac}$ & $8.2 \mathrm{ABa}$ & $9.0 \mathrm{Acd}$ & $8.0 \mathrm{ABd}$ & $0.0 \mathrm{Cf}$ & $0.0 \mathrm{Cb}$ \\
\hline RS10 & $0.0 \mathrm{Ea}$ & $4.0 \mathrm{Ce}$ & $5.0 \mathrm{Cf}$ & $7.6 \mathrm{Ba}$ & $12 \mathrm{Aa}$ & $8.0 \mathrm{Bd}$ & $0.0 \mathrm{Ef}$ & $0.0 \mathrm{~Eb}$ \\
\hline RS11 & $0.0 \mathrm{Da}$ & $0.0 \mathrm{Df}$ & $6.7 \mathrm{Ced}$ & $10.3 \mathrm{Aa}$ & $7.8 \mathrm{Be}$ & $8.4 \mathrm{Bcd}$ & $0.0 \mathrm{Df}$ & $0.0 \mathrm{Db}$ \\
\hline RS12 & $0.0 \mathrm{Da}$ & $9.6 \mathrm{Aa}$ & $6.0 \mathrm{Bef}$ & $10.2 \mathrm{Aa}$ & $9.0 \mathrm{Acd}$ & $5.4 \mathrm{Bef}$ & $1.5 \mathrm{Ce}$ & $0.0 \mathrm{Db}$ \\
\hline RS13 & $0.0 \mathrm{Ea}$ & $7.2 \mathrm{Bbc}$ & $6.0 \mathrm{Cef}$ & $8.4 \mathrm{Aa}$ & $9.4 \mathrm{Ac}$ & $6.6 \mathrm{BCe}$ & $1.5 \mathrm{De}$ & $0.0 \mathrm{~Eb}$ \\
\hline RS14 & $0.0 \mathrm{Ea}$ & $0.0 \mathrm{Ef}$ & $3.5 \mathrm{Dg}$ & $8.3 \mathrm{Ca}$ & $11.0 \mathrm{Ab}$ & $9.6 \mathrm{Bbc}$ & $0.0 \mathrm{Ef}$ & $0.0 \mathrm{~Eb}$ \\
\hline RS15 & $0.0 \mathrm{Ea}$ & $7.3 \mathrm{Cbc}$ & $10.0 \mathrm{ABab}$ & $9.0 \mathrm{Ba}$ & $10.7 \mathrm{Ab}$ & $\begin{array}{r}9.6 \\
\text { ABbc }\end{array}$ & $1.5 \mathrm{De}$ & $0.0 \mathrm{~Eb}$ \\
\hline RS16 & $0.0 \mathrm{Ea}$ & $8.3 \mathrm{Cb}$ & $9.0 \mathrm{BCbc}$ & $9.3 \mathrm{Ba}$ & $11.0 \mathrm{Ab}$ & $9.6 \mathrm{Bbc}$ & $4.8 \mathrm{Dd}$ & $0.0 \mathrm{~Eb}$ \\
\hline RS17 & $0.0 \mathrm{Ba}$ & $0.0 \mathrm{Bf}$ & $2.0 \mathrm{Bh}$ & $10.7 \mathrm{Aa}$ & $12.0 \mathrm{Aa}$ & $13.2 \mathrm{Aa}$ & $11.0 \mathrm{Aab}$ & $0.0 \mathrm{Bb}$ \\
\hline
\end{tabular}

Lowercase letter: Mean separation between different strains for each temperature.

Uppercase letter: Mean separation between different temperatures for each isolate.

\section{Effect of pH on mycelial growth of $\boldsymbol{R}$. solani isolates}

Diagnostic of the ANOVA results (Tab 5) revealed significant interaction between $R$. solani isolates and $\mathrm{pH}$ level $(\mathrm{P}<0.0001)$ and significant main effect of both $\mathrm{pH}$ level and isolates on growth rate. Average growth rate showed significant difference among different $\mathrm{pH}$ levels for each isolate. All sixteen isolates of $R$. solani were able to develop on PDA medium at all levels of $\mathrm{pH}$ within the range of 5-8.5 with certain similarities between average growth rate under $\mathrm{pH}=7$ and the control (Tab 6). The average growth rate also showed high value $(20.0 \mathrm{~mm} / \mathrm{d})$ for the isolate $\mathrm{RS} 1$ under $\mathrm{pH}=7$ and lower value $(1.5 \mathrm{~mm} / \mathrm{d})$ under $\mathrm{pH}=8.5$ for the isolate $\mathrm{RS} 10$.

Table 5 Analysis of variance (ANOVA) on growth rate of $R$. solani isolates under $\mathrm{pH}$ level effect

\begin{tabular}{llll}
\hline Source of variation & Degree of freedom & F-value & P-value \\
\hline Isolate & 15 & 630.42 & $<.0001$ \\
\hline $\mathbf{p H}$ & 5 & 1699.98 & $<.0001$ \\
\hline Isolate $\times \mathbf{p H}$ & 75 & 69.94 & $<.0001$ \\
\hline Block & 2 & 0.18 & 0.8395 \\
\hline
\end{tabular}

Within column, means followed by same lower case letters are not significantly different based on the LSD.

Within row, means followed by same upper case letters are not significantly different based on the LSD.
Table 6 Average growth rates $(\mathrm{mm} / \mathrm{d})$ of $R$. solani isolates under five $\mathrm{pH}$ levels

\begin{tabular}{lccccc}
\hline Isolate & $\mathbf{p H}=\mathbf{5}$ & $\mathbf{p H}=\mathbf{6}$ & $\mathbf{p H}=\mathbf{7}$ & $\mathbf{p H}=\mathbf{8}$ & $\mathbf{p H}=\mathbf{8 . 5}$ \\
\hline RS1 & $15.2 \mathrm{Da}$ & $16.2 \mathrm{CDb}$ & $20.0 \mathrm{Aa}$ & $18.6 \mathrm{Ba}$ & $11.3 \mathrm{Ea}$ \\
\hline RS3 & $14.2 \mathrm{Cab}$ & $19.3 \mathrm{Aa}$ & $19.0 \mathrm{Ab}$ & $17.8 \mathrm{Bb}$ & $9.7 \mathrm{Dd}$ \\
\hline RS4 & $6.4 \mathrm{Bh}$ & $7.3 \mathrm{ABj}$ & $8.3 \mathrm{Ak}$ & $6.3 \mathrm{Bk}$ & $4.0 \mathrm{Ce}$ \\
\hline RS5 & $14.8 \mathrm{Ba}$ & $13.5 \mathrm{Cd}$ & $19.8 \mathrm{Aab}$ & $14.2 \mathrm{BCc}$ & $10.6 \mathrm{Dbc}$ \\
\hline RS6 & $10.8 \mathrm{Aefg}$ & $10.4 \mathrm{Ag}$ & $10.5 \mathrm{Ai}$ & $10.9 \mathrm{Af}$ & $10.3 \mathrm{Ac}$ \\
\hline RS7 & $11.2 \mathrm{ABef}$ & $7.8 \mathrm{Cj}$ & $12.0 \mathrm{Ag}$ & $7.19 \mathrm{Cj}$ & $11.0 \mathrm{Bab}$ \\
\hline RS8 & $11.1 \mathrm{Bef}$ & $9.1 \mathrm{CDi}$ & $14.8 \mathrm{Acd}$ & $8.8 \mathrm{Di}$ & $3.2 \mathrm{Ef}$ \\
\hline RS9 & $10.2 \mathrm{Bfg}$ & $11.4 \mathrm{Aef}$ & $11.8 \mathrm{Agh}$ & $11.2 \mathrm{Af}$ & $2.2 \mathrm{Ch}$ \\
\hline RS10 & $10.3 \mathrm{Cfg}$ & $9.8 \mathrm{Ch}$ & $13.1 \mathrm{Af}$ & $11.2 \mathrm{Bf}$ & $1.5 \mathrm{Di}$ \\
\hline RS11 & $12.8 \mathrm{Bcd}$ & $11.7 \mathrm{Cef}$ & $9.6 \mathrm{Dj}$ & $12.8 \mathrm{Bd}$ & $4.4 \mathrm{Ee}$ \\
\hline RS12 & $9.7 \mathrm{Dg}$ & $14.4 \mathrm{Ac}$ & $11.1 \mathrm{Chi}$ & $11.9 \mathrm{Be}$ & $2.6 \mathrm{Egh}$ \\
\hline RS13 & $10.4 \mathrm{Defg}$ & $11.3 \mathrm{Cf}$ & $13.5 \mathrm{Aef}$ & $9.7 \mathrm{Eh}$ & $2.2 \mathrm{Fh}$ \\
\hline RS14 & $11.6 \mathrm{Cde}$ & $11.6 \mathrm{Cef}$ & $14.1 \mathrm{Bde}$ & $10.4 \mathrm{Eg}$ & $11.1 \mathrm{Dab}$ \\
\hline RS15 & $10.6 \mathrm{Cefg}$ & $11.9 \mathrm{Be}$ & $14.1 \mathrm{Ade}$ & $12.5 \mathrm{Bd}$ & $4.0 \mathrm{De}$ \\
\hline RS16 & $10.6 \mathrm{Eef}$ & $14.4 \mathrm{Bc}$ & $13.0 \mathrm{Cf}$ & $11.4 \mathrm{Def}$ & $3.1 \mathrm{Ffg}$ \\
\hline RS17 & $13.1 \mathrm{Cbc}$ & $11.6 \mathrm{Def}$ & $15.3 \mathrm{Ac}$ & $13.8 \mathrm{BCc}$ & $10.6 \mathrm{Dbc}$ \\
\hline Lof & & & &
\end{tabular}

Lowercase letter: Mean separation between different isolate for each $\mathrm{pH}$.

Uppercase letter: Mean separation between different $\mathrm{pH}$ for each isolate.

\section{Antifungal activity}

The ANOVA results (Tab 7) revealed significant interaction between isolates and EO $(\mathrm{P}<0.0001)$ and significant main effect of both EO and isolates on growth inhibition rate. The growth inhibition rates of eight $R$. solani isolates using seven EOs of Salvia sp., Cistus ladanifer L., Lavandula stoechas L., Thymus vulgaris L., Origanum compactum Benth., Rosmarinus officinalis L. and Eucalyptus sp. are shown in Figurel. The growth inhibition rate showed high value for the isolate RS1 (75.9\%) using the EO of Thymus vulgaris $\mathrm{L}$. and the lower value was for the isolate RS4 (1.9\%) using the EO of Rosmarinus officinalis L. EO of Origanum compactum showed the higher level of growth inhibition rates followed by Thymus vulgaris L. EO on all $R$. solani isolates except the RS1 isolate, suggesting the great potential of these two EOs in controlling the development of all R. solani isolates tested in this study. However, EO of Cistus ladanifer $\mathrm{L}$. showed the lowest level of growth inhibition rates on most of $R$. solani isolates (Figure 2).

Table7 Analysis of variance (ANOVA) of growth rate of $R$. solani isolates under EOs effect

\begin{tabular}{llll}
\hline Source of variation & Degree of freedom & F-value & P-value \\
\hline Isolate $(\mathbf{I})$ & 7 & 2319.51 & $<.0001$ \\
\hline EO & 6 & 25409.3 & $<.0001$ \\
\hline I $\times$ EO & 42 & 1035.34 & $<.0001$ \\
\hline Block & 2 & 2.34 & 0.1010 \\
\hline
\end{tabular}

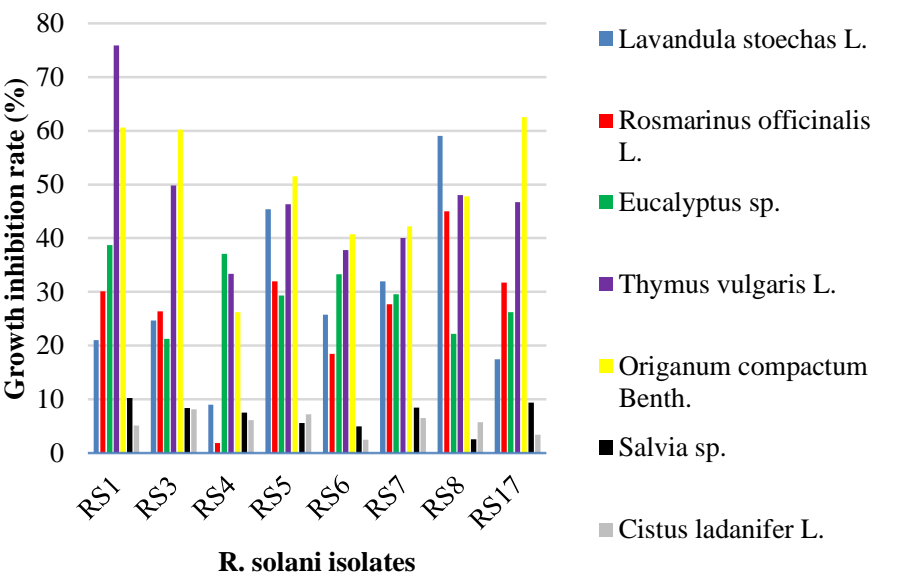

Figure1 Growth inhibition rates of $R$. solani isolates using plant Eos 

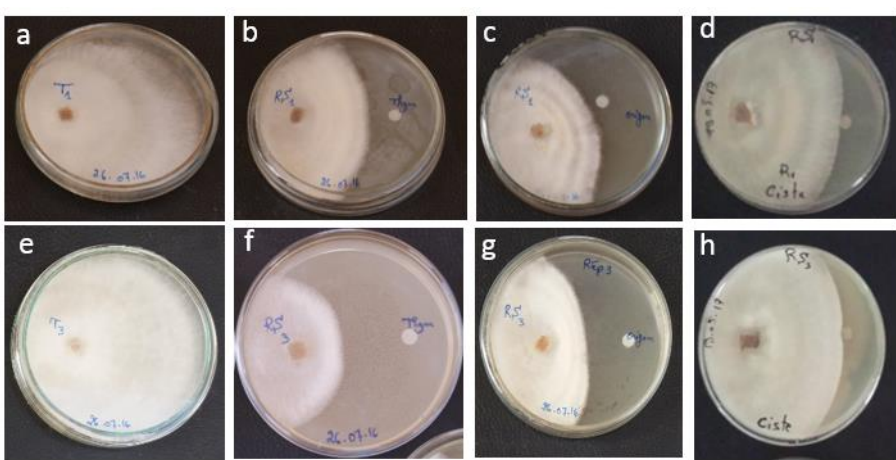

Figure 2 Mycelial growth inhibition of $R$. solani isolates RS1 (a,b,c,d) and RS3 $(\mathrm{e}, \mathrm{f}, \mathrm{g}, \mathrm{h})$ compared with control $(\mathrm{a}, \mathrm{e})$ using EOs of Thyme $(\mathrm{b}, \mathrm{f})$, Oregano $(\mathrm{c}, \mathrm{g})$ and Cistus $(\mathrm{d}, \mathrm{h})$

\section{Determination of Minimum Inhibitory Concentrations (MICs)}

Results of this assay showed that the plant EOs have different MIC on $R$. solani isolates. However, the MIC of T. vulgaris and O. compactum EOs on R. solani isolates was similar with an average of $0.03 \%$ (Figure 3 ). Whereas, the others EOs showed a MIC higher than $0.15 \%$. This difference could be due to the chemical compounds of each plant EO.
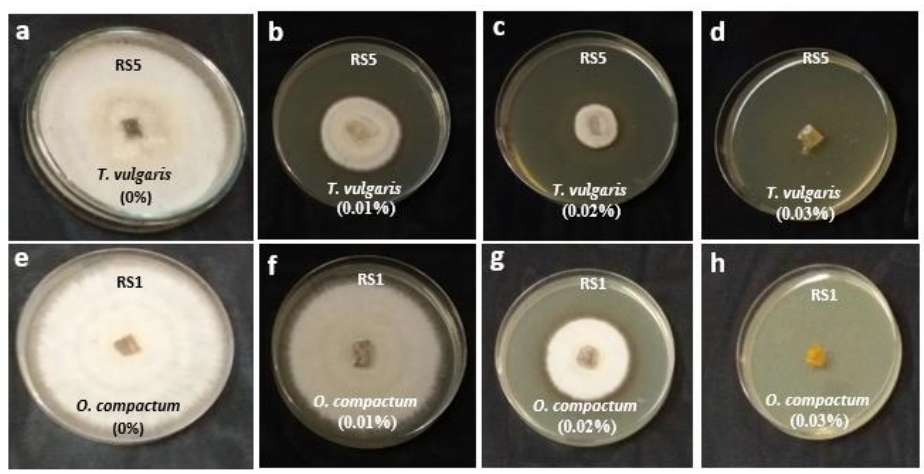

Figure 3 Mycelial growth inhibition of $R$. solani RS5 and RS1 compared to the control (a, e) using EOs of $T$. vulgaris and $O$. compactum with different concentrations: $0.01 \%(\mathrm{~b} ; \mathrm{f}), 0.02 \%(\mathrm{c} ; \mathrm{g})$ and $0.03 \%(\mathrm{~d} ; \mathrm{h})$

\section{Essential oil composition}

In this study, the GC-MS analysis revealed that the major compounds of the EOs examined were monoterpene hydro- carbons and phenolic monoterpenes. However, GC-MS analyses of $R$. officinalis, O. compactum, T. vulgaris, $R$ officinalis and Eucalyptus EOs conducted to the identification of different constituents (Tab 8). The major constituents of $O$. compactum EO were carvacrol $(61.78 \%), \gamma$-terpinene $(12.46 \%)$, p-cymene $(8.21 \%)$, and thymol $(7.01 \%)$. While T. vulgaris EO was composed primarily of thymol (47.79\%), p-cymene $(24.13 \%)$, and $\gamma$-terpinene $(8.19 \%)$. R. officinalis and Eucalyptus EOs were mainly composed of Cineole with concentrations of $46.28 \%$ and $67.08 \%$ respectively.

Table 8 GC-MS data for EO components identified

\section{$\%$ of essential oils}

\begin{tabular}{|c|c|c|c|c|}
\hline Compound & $\begin{array}{c}\text { Rosmarinus } \\
\text { officinalis }\end{array}$ & $\begin{array}{l}\text { Thymus } \\
\text { vulgaris }\end{array}$ & $\begin{array}{c}\text { Origanum } \\
\text { compactum }\end{array}$ & Eucalyptus sp. \\
\hline Thujene & - & 0.57 & 0.92 & - \\
\hline$\alpha$-Pinène & 11.94 & 0.54 & 0.59 & 3 \\
\hline Camphene & 4.76 & 0.16 & 0.08 & - \\
\hline Isoamylisovalerate & - & - & - & 0.47 \\
\hline$\beta$-Pinène & 3.05 & 0.11 & 0.12 & 0.24 \\
\hline Octen-3-ol & 0.2 & 0.32 & 1.17 & - \\
\hline 3-Octanone & - & 0.06 & 0.10 & - \\
\hline Myrcène & 1.35 & 1.34 & 1.43 & - \\
\hline 3-Octanol & - & 0.06 & - & - \\
\hline$\alpha$-phellandrène & 0.45 & 0.16 & 0.22 & - \\
\hline$\delta$-3-Carene & - & 0.07 & 0.08 & - \\
\hline Cinéole (Eucalyptol) & 46.28 & - & - & 67.08 \\
\hline Ocimène-Cis- $\beta$ & - & - & 0.13 & - \\
\hline$\alpha$-Terpinène & 0.98 & 1.72 & 1.85 & - \\
\hline$\gamma$-Terpinène & 1.32 & 8.19 & 12.46 & 0.94 \\
\hline Terpinolène & 0.6 & 0.10 & 0.08 & - \\
\hline Pulégone & - & - & - & 1.62 \\
\hline$\rho$-Cymene & 1.58 & 24.13 & 8.21 & 11.51 \\
\hline Limonène & - & 0.38 & 0.23 & - \\
\hline Cis-Linalool Oxide & - & 0.09 & - & - \\
\hline Fenchyl-alcool & - & - & - & 0.25 \\
\hline Linalool & 1.81 & 3.06 & 0.86 & - \\
\hline$\beta$-fenchyl alcohol & - & - & - & 3.12 \\
\hline p-Cymenène & - & 0.07 & - & - \\
\hline Bicyclo 3,1,1-hept-3-en-2-ol & - & - & - & 0.86 \\
\hline 1,8-Cineole & - & 0.12 & - & - \\
\hline Bicyclo 2,2,1-hept-3-one & - & - & - & 0.24 \\
\hline Camphor & 12.32 & 0.05 & - & 0.34 \\
\hline Pinocamphone & 0.2 & - & - & - \\
\hline Pinocarvone & 0.23 & - & - & - \\
\hline Bornéol & 4.49 & 0.45 & 0.14 & 0.51 \\
\hline Iso-pinocamphone & 0.28 & - & - & - \\
\hline Thujol & - & - & - & 0.55 \\
\hline Terpinen-4-ol & 1.14 & 0.59 & 0.42 & 1.01 \\
\hline Cis-Dishydro Carvone & - & 0.06 & 0.06 & - \\
\hline$\alpha$-Terpinéol & 4.1 & - & - & - \\
\hline Verbenone & 0.6 & - & - & - \\
\hline Bornyl acétate & 1.38 & - & - & - \\
\hline Thymol Méthyl Ether & - & 0.04 & - & - \\
\hline Carvacrol Méthyl Ether & - & 0.05 & - & - \\
\hline
\end{tabular}




\begin{tabular}{lcccc}
\hline Carvacrol & - & 5.03 & $\mathbf{6 1 . 7 8}$ & 0.75 \\
\hline Thymol & - & $\mathbf{4 7 . 7 9}$ & 7.01 & - \\
\hline (E)Caryophyllène & - & 1.76 & 1.47 & 0.53 \\
\hline Trans-Caryophyllène & 0.75 & - & - & -26 \\
\hline$\alpha$-Humulène & - & 0.06 & 0.06 & - \\
\hline$\alpha$-Selinène & - & 0.04 & - & - \\
\hline$\alpha$-Murolène & - & 0.01 & - & - \\
\hline$\beta$-Bisabolène & - & 0.05 & 0.13 & - \\
\hline$\gamma$-Cadinène & - & 0.07 & 0.03 & - \\
\hline$\delta$-Cadinène & - & 0.16 & 0.06 & - \\
\hline Caryophyllène Oxide & - & 0.80 & - & - \\
\hline Isoaromadendrène & - & - & - & 0.27 \\
\hline Aromadendrène & - & - & - & 0.95 \\
\hline Viridiflorol & - & - & - & 0.43 \\
\hline$\gamma$-gurjunène & - & - & - & 2.28 \\
\hline$\delta$-gurjunène & - & - & 98.89 \\
\hline Total & 99.81 & 98.35 & 97.56 \\
\hline
\end{tabular}

\section{DISCUSSION AND CONCLUSION}

Diseases induced by $R$. solani are challenging because this fungi survives for many years as mycelium or as sclerotia in organic matter or soil under different conditions and has an important host range (Ismail \& Ismail, 2011). Similar results to our current study have also been reported by many other investigator (Chang, 1985; Dubey et al., 2012; Jaaffar et al., 2016). For $R$. solani, the most favorable temperature regime was from 25 to $35^{\circ} \mathrm{C}$ (Csöndes et al., 2007), also Chang (1985) found that both mycelial growth and sclerotial developpement of $R$. solani were maximal at $\mathrm{pH} 7$ which confirm the results of our study. Sharma and Chowdhury (1984) observed that $R$. solani has a low incidence in cauliflower at neutral $\mathrm{pH}$ comparing to $\mathrm{pH} 7.4$ - 8.5. Also, Marcelo and Vega (1988) found that the most favorable $\mathrm{pH}$ for $\mathrm{R}$. solani development was in $\mathrm{pH} 6$ 6.5. Moreover, Kobayashi (1985) found that soil $\mathrm{pH}$ has a direct influence on the hyphal growth of $R$. solani.

In the last several years, many researches have been conducted for the development of safer antifungal agents such as EOs and plants extracts to control plant pathogens in agriculture (Bajpai and Kang, 2010). The EOs derived from medicinal and aromatic plants have been reported to show interesting antimicrobial effects against fungi, bacteria and viruses (Reichling et al., 2009). Katooli et al. (2011) evaluated the effect of EOs for suppressing the mycelia growth of $R$. solani. The antifungal activity of thyme EO has well proved agains fungi such as $R$. solani (Zambonelli et al., 1996) and in our current study, both EOs of $T$. vulgaris and $O$. compactum showed the highest level of growth inhibition rates on $R$. solani isolates.

In the present study, among the EOs that were selected for GC analysis, the carvacrol and thymol were identified as main constituents for $O$. compactum and T. vulgaris, respectively. It is well known that some plants contain compound that are able to inhibit microbial growth (Naovi et al., 1991). Additionally, antagonistic or synergistic effects between some EOs constituents may also affect the observed antimicrobial activity of these EOs. Didry et al. (1993) reported a synergistic activity of thymol and carvacrol against some bacteria.

Origanum compactum and T. vulgaris are two aromatic and medicinal plants belonging to the Laminacea family, which is a source for many plants with therapeutic benefits. These plants are largely distributed in north and east of Morocco and commonly used as spices and condiments (Zantar et al., 2014). The chemical composition of $O$. compactum and T. vulgaris EOs has been described by different authors (Imelouane et al., 2009; Govaris et al., 2011). An important diversity has been demontrated; however, carvacrol and thymol remain the major constituents. According to Di Pasqua et al. (2007) thymol can damage the citrate metabolic pathway and influence the enzymes involved in ATP synthesis. Also, carvacrol showed impact on cell membrane structure by increasing the fluidity and permeability of the membrane.

The use of these EOs tested on $R$. solani fungus may be a good source of new alternative active ingredient for an effective and sustainable management of this disease. Also, EOs have two importants advantages; low toxicity for people and environment due to their natural characteristics and low risk for resistance development by pathogenic microorganisms. However, further formulation and field experiments are necessary to achieve this goal.

\section{REFERENCES}

Abe, H. (1978). Anastomosis groups of isolates of Rhizoctonia solani Kuhn from potatoes. Bull Hokkaido Pref Agric Exp Stn, 40, 61-70.

Adams, R. P. (2007). Identification of essential oil components by gas chromatography/mass spectrometry (Vol. 456). Carol Stream, IL: Allured publishing corporation.

Bajpai, V. K., \& Kang, S. C. (2010). Antifungal activity of leaf essential oil and extracts of Metasequoia glyptostroboides Miki ex Hu. Journal of the American Oil Chemists' Society, 87(3), 327-336. https://doi.org/10.1007/s11746-009-15006
Chang, Y. C. (1985). Effect of temperature, $\mathrm{pH}$ and water potential on mycelial growth and sclerotial formation of Rhizoctonia solani AG 1. Chung-hua nung yeh yen chiu= Journal of agricultural research of China. 34 (4): 454- 463.

Csöndes, I., Kadlicskó, S., \& Gáborjányi, R. (2007). Effect of different temperature and culture media on the growth of Macrophomina phaseolina Communications in agricultural and applied biological sciences, 72(4), 839-848. Di Pasqua, R., Betts, G., Hoskins, N., Edwards, M., Ercolini, D., \& Mauriello, G. (2007). Membrane toxicity of antimicrobial compounds from essential oils. Journal of agricultural and food chemistry, 55(12), 4863-4870 https://doi.org/10.1021/jf0636465

Didry, N. P., Dubreuil, L., \& Pinkas, M. (1993). Antibacterial activity of thymol, carvacrol and cinnamaldehyde alone or in combination. Die Pharmazie, 48(4), 301-304.

Djébali, N., Elkahoui, S., Taamalli, W., Hessini, K., Tarhouni, B., \& Mrabet, M. (2014). Tunisian Rhizoctonia solani AG3 strains affect potato shoo macronutrients content, infect faba bean plants and show in vitro resistance to azoxystrobin. Australasian Plant Pathology, 43(3), 347-358. https://doi.org/10.1007/s13313-014-0277-8

Dubey, S. C., Tripathi, A., \& Upadhyay, B. K. (2012). Molecular diversity analysis of Rhizoctonia solani isolates infecting various pulse crops in differen agro-ecological regions of India. Folia microbiologica, 57(6), 513524.https://doi.org/10.1007/s12223-012-0165-y

Duru, M. E., Cakir, A., Kordali, S., Zengin, H., Harmandar, M., Izumi, S., \&

Hirata, T. (2003). Chemical composition and antifungal properties of essential oils of three Pistacia species. Fitoterapia, 74(1), 170-176

Goswami, B. K., Rahaman, M. M., Hoque, A. K. M. A., Bhuiyan, K., \& Mian, I. H. (2011). Variations in different isolates of Rhizoctonia solani based on temperature and pH. Bangladesh Journal of Agricultural Research, 36(3), 389 396. https://doi.org/10.3329/bjar.v36i3.9267

Goudjal, Y., Toumatia, O., Yekkour, A., Sabaou, N., Mathieu, F., \& Zitouni, A (2014). Biocontrol of Rhizoctonia solani damping-off and promotion of tomato plant growth by endophytic actinomycetes isolated from native plants of Algerian Sahara. Microbiological Research, 169(1), 59-65. https://doi.org/10.1016/j.micres.2013.06.014

Govaris, A., Botsoglou, E., Sergelidis, D., \& Chatzopoulou, P. S. (2011) Antibacterial activity of oregano and thyme essential oils against Listeria monocytogenes and Escherichia coli O157: H7 in feta cheese packaged under modified atmosphere. LWT-Food Science and Technology, 44(4), 1240-1244. https://doi.org/10.1016/j.lwt.2010.09.022

Gul, H. I., Ojanen, T., \& Hänninen, O. (2002). Antifungal evaluation of bis Mannich bases derived from acetophenones and their corresponding piperidinols and stability studies. Biological and Pharmaceutical Bulletin, 25(10), 1307 1310.https://doi.org/10.1248/bpb.25.1307

Güllüce, M., Sökmen, M., Şahin, F., Sökmen, A., Adigüzel, A., \& Özer, H. (2004). Biological activities of the essential oil and methanolic extract of Micromeria fruticosa (L) Druce ssp serpyllifolia (Bieb) PH Davis plants from the eastern Anatolia region of Turkey. Journal of the Science of Food and Agriculture, 84(7), 735-741. https://doi.org/10.1002/jsfa.1728

Habbadi, K., Meyer, T., Vial, L., Gaillard, V., Benkirane, R., Benbouazza, A., ... \& Lavire, C. (2018). Essential oils of Origanum compactum and Thymus vulgaris exert a protective effect against the phytopathogen Allorhizobium vitis Environmental Science and Pollution Research, 25(30), 29943-29952. https://doi.org/10.1007/s11356-017-1008-9

Huang, X., Zhang, N., Yong, X., Yang, X., \& Shen, Q. (2012). Biocontrol of Rhizoctonia solani damping-off disease in cucumber with Bacillus pumilus SQR N43. Microbiological Research, 167(3), 135-143. https://doi.org/10.1016/j.micres.2011.06.002

Hyakumachi, M., Mushika, T., Ogiso, Y., Toda, T., Kageyama, K., \& Tsuge, T. (1998). Characterization of a new cultural type (LP) of Rhizoctonia solani AG2-2 isolated from warm-season turfgrasses, and its genetic differentiation from other 
cultural types. Plant Pathology, 47(1), 1-9.https://doi.org/10.1046/j.1365$\underline{3059.1998 .00212 . \mathrm{x}}$

Imelouane, B., Amhamdi, H., Wathelet, J. P., Ankit, M., Khedid, K., \& El Bachiri, A. (2009). Chemical composition and antimicrobial activity of essential oil of thyme (Thymus vulgaris) from Eastern Morocco. Int. J. Agric. Biol, 11(2), 205-208.

Ismail, A. E. W. A., \& Ismail, M. M. (2011). Antagonistic activity of some fungi and cyanobacteria species against Rhizoctonia solani. International Journal of Plant Pathology, 2(3), 101-114. DO1: 10.3923/ijpp.2011.101.114

Isman, M. B., \& Machial, C. M. (2006). Pesticides based on plant essential oils: from traditional practice to commercialization. Advances in phytomedicine, 3, 2944. https://doi.org/10.1016/S1572-557X(06)03002-9

Jaaffar, A. K. M., Paulitz, T. C., Schroeder, K. L., Thomashow, L. S., \& Weller, D. M. (2016). Molecular characterization, morphological characteristics, virulence, and geographic distribution of Rhizoctonia spp. in Washington State Phytopathology, 106(5), 459-473.https://doi.org/10.1094/PHYTO-09-15-0208-R Katooli, N., Maghsodlo, R., \& Razavi, S. E. (2011). Evaluation of eucalyptus essential oil against some plant pathogenic fungi. Journal of Plant Breeding and Crop Science, 3(2), 41-43.

Kobayashi, W.H. (1985). Natural suppression of soil borne plant diseases. Plant protection Bulletion, Taiwan 27(3). 17 1-178.

Kotba, I., Achouri, M., Benbouazza, A., Touhami, A. O., \& Douira, A. (2018) Morphological, Pathogenic and Molecular Characterisation of Rhizoctonia solani strains isolated from Potato. Annual Research \& Review in Biology, 1-16. https://doi.org/10.9734/ARRB/2018/44926

Lahlali, R., \& Hijri, M. (2010). Screening, identification and evaluation of potential biocontrol fungal endophytes against Rhizoctonia solani AG3 on potato plants. FEMS microbiology letters, 311(2), 152-159.

Naher, L., Ali, M. A., Dey, T. K., Islam, M. M., \& Ismail, A. (2014). Evolution of disease and potential biocontrol activity of Trichoderma SP. against Rhizoctonia solani on potato. Bioscience Journal, 30(4).

Naovi, S. A., Khan, M. S., Vohora, S. B., \& Naqvi, S. (1991). Antibacterial, antifungal and anthelmintic investigations on Indian medicinal plants.

Negahban, M., Moharramipour, S., \& Sefidkon, F. (2007). Fumigant toxicity of essential oil from Artemisia sieberi Besser against three stored-product insects. Journal of stored products research, 43(2), 123-128.

Rashad, Y. M., Abdel-Fattah, G. M., Hafez, E. E., \& El-Haddad, S. A. (2012) Diversity among some Egyptian isolates of Rhizoctonia solani based on anastomosis grouping, molecular identification and virulence on common bean African Journal of Microbiology Research, 6(37), 6661-6667. DOI: 10.5897/AJMR12.109

Reichling, J., Schnitzler, P., Suschke, U., \& Saller, R. (2009). Essential oils of aromatic plants with antibacterial, antifungal, antiviral, and cytotoxic propertiesan overview. Complementary Medicine Research, 16(2), 7990..DOI: $10.1159 / 000207196$.

Salunke, V. N., Armarkar, S., \& Ingle, R. W. (2008). Efficacy of fungicides and antagonistic effect of bio-agent Rhizoctonia bataticola isolates. Annals of Plant Physiology, 220(1), 134-137.

Sneh B, Burpee L, Ogoshi A. (1991). Identification of Rhizoctonia species, pp. 133. American Phytopathological Society Press, Saint Paul, USA https://www.cabdirect.org/cabdirect/search/?q=bn\%3a\%22089054123X\%22 Topps, J. H., \& Wain, R. L. (1957). Investigations on fungicides. III. The fungitoxicity of 3-and 5-alkyl-salicylanilides and para-chloroanilides. Annals of Applied Biology, 45(3), 506-511. https://doi.org/10.1111/j.17447348.1957.tb05888.x

Zambonelli, A., d'Aulerio, A. Z., Bianchi, A., \& Albasini, A. (1996). Effects of essential oils on phytopathogenic fungi in vitro. Journal of Phytopathology, 144(9-10), 491-494. https://doi.org/10.1111/j.1439-0434.1996.tb00330.x

Zantar, S., Yedri, F., Mrabet, R., Laglaoui, A., Bakkali, M., \& Zerrouk, M. H. (2014). Effect of Thymus vulgaris and Origanum compactum essential oils on the shelf life of fresh goat cheese. Journal of Essential Oil Research, 26(2), 76-84 https://doi.org/10.1080/10412905.2013.871673 